\title{
Penerapan Non Delay Schedule Dengan Mempertimbangkan Machine Availability Constraint untuk Meminimasi Makespan pada PT Autotech Perkasa Mandiri, Cikarang, Jawa Barat
}

\author{
Anastasia Lidya Maukar ${ }^{1}$, Ineu Widaningsih Sosodoro ${ }^{2}$, Stefanus Setiady ${ }^{3}$ \\ ${ }^{1,2,3)}$ Faculty of Engineering, Industrial Engineering Department, President University \\ Jl. Ki Hajar Dewantara \\ Kota Jababeka,Cikarang, Bekasi - Indonesia 17550 \\ Email: almaukar@president.ac.id, inesosodoro@yahoo.co.id, adysetiady86@gmail.com
}

\begin{abstract}
One of the efforts to increase production efficiency is by implementing the right scheduling. PT Autotech Perkasa Mandiri is the job shop production system. Currently implements a heuristic method with a priority dispatch rule, namely the Earliest Due Date (EDD). The EDD rule has the highest priority for the job with the earliest due date to be processed on a machine. This study is to purpose a more optimal scheduling by comparing the makespan of the current schedule with the proposed one. Previous research is the non delay schedule without considering machine availability constraints. In this study, machine availability constraints are taken into account, thus, they are more realistic when applied to the actual problem. The algorithm used is a non delay schedule with working time window (WT-NSA). Machine availability constraints that are taken into account are lunch-break hours (12: 00-13: 00) and shift changes (17: 00-08: 00). From the analysis, it is obtained that makespan from non delay schedule is 23 hours 6 minutes, while makespan from WT-NSA is 26 hours 6 minutes, and makespan from EDD schedule is 38 hours 54 minutes. Non-delay schedule has the smallest makespan, which is 23 hours 6 minutes, but WT-NSA is more realistic when applied to the real problem.
\end{abstract}

Keywords: Job Shop, Earliest Due Date, Non Delay Schedule, Machine Availability Constraint, Working Time Window, Makespan.

\section{ABSTRAK}

Dalam upaya meningkatkan efektifitas dan efisiensi produksi, ada beberapa cara yang dapat dilakukan, salah satunya adalah dengan menerapkan penjadwalan yang tepat. Dengan sistem produksi job shop, metode penjadwalan yang saat ini diterapkan PT Autotech Perkasa Mandiri adalah metode heuristik dengan priority dispatch rule, yaitu Earliest Due Date (EDD), dimana job yang memiliki due date yang paling awal merupakan job yang memiliki prioritas paling tinggi untuk diproses pada sebuah mesin. Tujuan dari penelitian ini adalah memberikan usulan penjadwalan yang lebih optimal dengan membandingkan makespan dari penjadwalan yang sekarang dengan penjadwalan yang diusulkan. Penelitian sebelumnya yaitu non delay schedule tanpa memperhitungkan machine availability constraint. Pada penelitian ini machine availability constraint diperhitungkan, agar lebih reaslistik jika diaplikasikan ke dalam permasalahan sebenarnya. Algoritma yang digunakan adalah non delay schedule working time window (WT-NSA). Machine availability constraint yang diperhitungkan adalah jam istirahat (12:00-13:00) dan pergantian shift (17:00-08:00). Dari analisis yang dilakukan diperoleh makespan dari non delay schedule adalah 23 jam 6 menit, sedangkan makespan dari WT-NSA adalah 26 jam 6 menit, dan makespan dari EDD schedule 38 jam 54 menit. Non delay schedule memiliki makespan paling kecil yaitu 23 jam 6 menit, namun WT-NSA lebih realistik apabila diaplikasikan ke dalam permasalahan sebenarnya.

Kata kunci: Job Shop, Earliest Due Date, Non Delay Schedule, Machine Availability Constraint, Working Time Window, Makespan.

\section{Pendahuluan}

PT Autotech Perkasa Mandiri merupakan perusahaan industri manufaktur yang memproduksi precision part, jig \& fixture, automation \& dies. Dimana barang-barang tersebut merupakan alat bantu pendukung proses produksi customer. Sebagai bagian dari rantai suplai industri manufaktur, 
PT Autotech Perkasa Mandiri dituntut untuk menghasilkan barang dengan kualitas tinggi dengan pengiriman yang tepat waktu.

Sistem produksi di PT Autotech Perkasa Mandiri adalah job shop. Menurut Baker (1995) karakteristik job shop yaitu ada sejumlah $\mathrm{m}$ mesin dan sejumlah $\mathrm{n}$ job. Setiap job memiliki routing yang dapat berbeda satu sama lain, dan lebih kompleks dari flow shop (Champbell, Dudek, dan Smith, 1970). Selain itu, penjadwalan job shop adalah setiap job atau pesanan memiliki rute pengerjaan yang berbeda-beda, sesuai permintaan konsumen (complex routing) (Pinedo dan Chao, 1999). Karena kompleksnya aliran maka penjadwalan pun sangat kompleks. Aliran bersifat diskrit, dan part tidak bersifat multiguna (part yang mungkin menjadi work-in ptocess (WIP) pada job yang satu tidak bisa digunakan pada job yang lain).

Bentuk sederhana dari model ini mengasumsikan bahwa setiap job hanya melewati satu jenis mesin sebanyak satu kali dalam rutenya pada proses tersebut. Namun ada juga model lainnya dimana setiap job diperbolehkan untuk melewati mesin sejenis lebih dari satu kali pada rutenya. Model ini disebut juga job shop dengan recirculation (pengulangan).

Penjadwalan produksi yang saat ini diterapkan adalah dengan metode Earliest Due Date (EDD), yaitu dengan mengurutkan job berdasarkan due date dari customer dengan mengabaikan waktu kedatangan job dan total waktu proses setiap job. Artinya, job yang memiliki due date paling awal diantara job lain merupakan job yang memiliki prioritas tinggi untuk diproses pada sebuah mesin. Hal ini bertujuan agar meminimasi terjadinya keterlambatan pengiriman ke customer (Giffler dan Thompson, 1960). Data hasil observasi di lapangan mencatat bahwa makespan dari 11 job yang dijadwalkan pada minggu pertama bulan mei 2016 dengan metode earliest due date adalah sebesar 38 jam 54 menit.

Menurut Baker (1974), tujuan penjadwalan pada umumnya adalah meningkatkan produktifitas mesin, yaitu dengan mengurangi waktu mesin menganggur. Selain itu mengurangi persediaan barang setengah jadi dengan jalan mengurangi jumlah rata-rata pekerjaan yang menunggu dalam antrian suatu mesin karena mesin tersebut sibuk. Kemudian, mengurangi keterlambatan suatu pekerjaan, setiap pekerjaan mempunyai batas waktu (due date) penyelesaian, jika pekerjaan tersebut diselesaikan melewati batas waktu yang ditentukan maka pekerjaan tersebut dinyatakan terlambat. Dengan metode penjadwalan yang tepat maka keterlambatan ini dapat dikurangi, baik waktu maupun frekuensi.

Pada penelitian sebelumnya dengan judul "Usulan Penerapan Non Delay Schedule untuk Meminimasi Makespan di PT Autotech Perkasa Mandiri" (Stefanus Setiady, 2016), mencatat bahwa makespan dari 11 job yang sama, yang dijadwalkan pada minggu pertama bulan mei 2016, dengan metode non delay schedule adalah sebesar 23 jam 6 menit. Kemudian pada penelitian tersebut kendala ketersediaan mesin adalah tidak diperhitungkan, sehingga diasumsikan bahwa mesin selalu tersedia dan bekerja selama 8 jam per hari tanpa memperhitungkan jam istirahat dan pergantian shift. Menurut Baker (1974) Non Delay Schedule (NSA) adalah jadwal aktif dimana tidak ada mesin yang menganggur jika dapat memulai operasi tertentu, tujuannya adalah untuk meminimasi makespan.

Penjadwalan job shop dengan memperhitungkan kendala ketersediaan mesin adalah lebih kompleks dari penjadwalan job shop tanpa memperhitungkan kendala ketersediaan mesin. Algoritma penjadwalan job shop dengan memperhitungkan kendala ketersediaan mesin adalah lebih baik ketika diaplikasikan ke dalam permasalahan yang sebenarnya. Dalam sebuah hari kerja (working day) adalah termasuk jam kerja (working period) dan jam istirahat (breaking period). Working period adalah waktu dimana sebuah job dikerjakan pada sebuah mesin dan breaking period adalah waktu dimana mesin berhenti mengerjakan sebuah job. Working time window adalah algoritma yang digunakan untuk menghitung finish time baru apabila breaking period terjadi di antara waktu operasi (Ploydanai dan Mungwattana, 2010).

Pada penelitian kali ini kendala ketersediaan mesin diperhitungkan, yaitu adanya jam istirahat (breaking period 1) pada jam 12:00-13:00 (1 jam) dan pergantian shift (breaking period 2) pada jam 17:00-08:00 hari berikutnya. Dengan demikian diperlukan algoritma baru untuk menyelesaikan permasalahan penjadwalan job shop dengan memperhitungkan kendala ketersediaan mesin untuk meminimasi makespan yang dapat diaplikasikan ke dalam permasalahan yang sebenarnya. Penelitian kali ini akan membandingkan makespan dan utilisasi mesin antara penjadwalan EDD, penjadwalan non delay (NSA), dan penjadwalan non delay dengan working time window (WT-NSA). 


\section{Material dan Metode}

Dalam melakukan analisis, beberapa data yang diperlukan telah dikumpulkan. Data yang digunakan pada penelitian ini adalah data yang diambil dari departemen PPIC dan Produksi PT Autotech Perkasa Mandiri, berupa data job/pesanan, dan fasilitas produksi yang digunakan. Dalam penelitian ini akan diusulkan suatu metode pejadwalan job shop non-deay dan non delay dengan working time window (WT-NSA). Adapun notasi model matematika job shop scheduling secara umum adalah sebagai berikut :

$f_{i, j}=$ finish time dari job $j$ pada mesin $i$

$t_{i, j}=$ waktu mulai dari job $j$ pada mesin $i$

$p_{i, j}=$ waktu proses dari job $j$ pada mesin $i$

$\mathrm{C}_{\max }=$ makespan (finish time dari job atau operasi paling akhir).

\subsection{Algoritma Non Delay Schedule}

Non delay schedule merupakan jadwal aktif, dimana tidak ada mesin mengangur apabila dapat memulai operasi tertentu. Langkah pertama dari non delay schedule adalah menghitung seluruh waktu proses dari seluruh operasi untuk setiap job yang dapat dikerjakan dalam tabel iterasi. Kemudian, operasi dengan waktu proses paling kecil dan finish time paling awal dipilih. Lalu, operasi yang dapat dikerjakan diperbarui dalam tabel iterasi dan langkah yang sama diteruskan sampai seluruh operasi terpilih (Ploydanai dan Mungwattana, 2010).

\subsection{Algoritma Working Time Window}

Algoritma working time window digunakan untuk menghitung finish time baru dengan memperhitungkan kendala ketersediaan mesin. Algoritma ini tepat digunakan untuk pabrik dengan banyak mesin, banyak job, dengan beberapa breaking period. Dalam satu hari kerja terdapat jam kerja (working period) dan jam istirahat (breaking period). Jam kerja (working period) adalah waktu dimana job dikerjakan pada sebuah mesin. Jam istirahat (breaking period) adalah waktu dimana mesin berhenti mengerjakan sebuah job. Jika breaking period tidak terjadi di antara waktu operasi, maka finish time $=$ start time + processing time. Sebaliknya, jika breaking period terjadi di antara waktu operasi, maka finish time dari operasi tersebut harus dihitung kembali (Ploydanai dan Mungwattana, 2010). Perhitungan dalam algoritma working time window adalah sebagai berikut :

$f_{i, j}=t_{i, j}+p_{i, j}$, dengan aturan sebagai berikut :

$b_{1}=t_{i, j} \leq \mu_{a, B} \leq f_{i, j}$ (true) ; sebaliknya (false)

$b_{2}=t_{i, j} \leq \gamma_{a, B} \leq f_{i, j}$ (true); sebaliknya (false)

$b_{3}=\mu_{a, B} \leq t_{i, j} \leq \gamma_{a, B}(1)$; sebaliknya (0)

$b_{4}=\mu_{a, b} \leq f_{i, j} \leq \gamma_{a, b}(1) ;$ sebaliknya (0)

$a=$ nomor hari kerja

$B=$ nomor breaking period

$\mu_{a, b}=$ Waktu dari sebuah mesin berhenti

$y_{a, b}=$ Waktu dari sebuah mesin beroperasi kembali

Selanjutnya untuk menentukan finish time yang baru dapat dilakukan dengan if then else rule berikut ini :

If, $\sim b_{1} \wedge b_{2} \wedge b_{3} \wedge \sim b_{4}$, then : $t_{i, j}=y_{a, B}$ and $f_{i, j}=f_{i, j}+\left(f_{i, j}-\mu_{a, b}\right)$

Else if, $b_{1} \wedge b_{2} \wedge b_{3} \wedge \sim b_{4}$, then : $t_{i, j}=\gamma_{a, b}$ and $f_{i, j}=f_{i, j}+\left(\gamma_{a, b}-\mu_{a, b}\right)$

Else if, $b_{1} \wedge b_{2} \wedge \sim b_{3} \wedge \sim b_{4}$, then : $t_{i, j}=\mu_{a, b}$ and $f_{i, j}=f_{i, j}+\left(y_{a, b}-\mu_{a, b}\right)$

Else if, $b_{1} \wedge \sim b_{2} \wedge \sim b_{3} \wedge b_{4}$, then : $t_{i, j}=\mu_{a, b}$ and $f_{i, j}=f_{i, j}+\left(\gamma_{a, b}-\mu_{a, b}\right)$

Algoritma working time window merupakan algoritma rekursif, yaitu digunakan secara berulang hingga finish time seluruh job selesai dihitung. 


\subsection{Algoritma Non Delay Schedule dengan Working Time Window}

Algoritma non delay dengan working time window (WT-NSA) adalah algoritma yang dikembangkan dari non delay schedule dengan mempertimbangkan kendala ketersediaan mesin, yaitu dengan algoritma working time window untuk menentukan finish time dengan machine availability constraint. Algoritma ini bertujuan untuk meminimasi makespan dan dapat diaplikasikan ke permasalahan yang nyata. Langkah pertama, algoritma menghitung finish time dari seluruh operasi untuk setiap job jika operasi tersebut siap dikerjakan. Selanjutnya, algoritma memeriksa dan menghitung ulang finish time dengan menggunakan algoritma working time window. Kemudian, operasi dengan start time paling awal atau paling dekat dipilih. Jika beberapa job memiliki start time yang sama, maka algoritma memilih operasi dengan finish time paling dekat. Setelah itu, algoritma memperbarui operasi yang siap untuk dikerjakan pada mesin. Operasi yang terpilih tercatat dalam urutan untuk memperbarui finish time saat waktu operasi berubah. Kemudian, iterasi diteruskan sampai seluruh operasi untuk setiap job selesai (Ploydanai dan Mungwattana, 2010).

\subsection{Langkah-langkah Penelitian}

Langkah-langkah penyelesaian masalah dalam melakukan penelitian, dimana fokus dari penelitian ini adalah memperoleh usulan metode penjadwalan yang tepat untuk meminimasi makespan. Sebagai langkah awal, dilakukan pengambilan data yang berupa data sekunder yang diambil dari departemen terkait, yaitu PPIC. Berikut adalah data yang diambil Data job pada 2 Mei 2016, Fasilitas mesin yang digunakan dan Gantt chart, makespan dan utilisasi mesin dengan menggunakan penjadwalan saat ini (EDD schedule). Adapun utilisasi mesin adalah perbandingan antara waktu yang digunakan dalam menyelesaikan seluruh job dengan waktu yang tersedia (jam kerja).

Kemudian dengan data job dan fasilitas mesin yang sama dilakukan analisis dan pengolahan data dengan metode penjadwalan non delay. Pada tahap ini dilakukan pengolahan data sesuai dengan algoritma penjadwalan non delay. Kemudian hasil dari hasil penjadwalan non delay, disusunlah Gantt chart dan diperoleh makespan dan utilisasi mesin dari penjadwalan non delay untuk job yang masuk pada 2 Mei 2016.

Selanjutnya, dengan data job dan fasilitas mesin yang sama dilakukan penjadwalan dengan algoritma WT-NSA, dimana jam istirahat (12:00-13:00) dan pergantian shift (17:00-08:00) diperhitungkan dalam penjadwalan non delay agar lebih realistic dengan menggunakan algoritma WT-NSA. Kemudian disusunlah Gantt chart, perhitungan makespan dan utilisasi dari algoritma WTNSA ini.

Pada tahap selanjutnya dilakukan perbadingan antara makespan dan utilisasi mesin dari EDD schedule, non delay schedule, dan algoritma WT-NSA yang memperhitungkan machine availability constraint. Dimana hasil perbandingan yang dilakukan akan menjadi hasil dari penelitian yang dilakukan antara kondisi saat ini dengan metode yang diusulkan.

Tahap ini merupakan tahap dimana usulan yang dilakukan dalam penelitian ini dapat diterima atau ditolak. Apabila makespan dari penjadwalan non delay lebih tinggi dari makespan dengan penjadwalan sebelumnya, maka penelitian ini perlu ditinjau ulang (mengganti dengan metode lain), sebaliknya apabila makespan dari non delay lebih kecil, maka usulan dari penelitian ini dapat dilanjutkan untuk diperiksa dan menjadi data untuk pengambilan keputusan dalam penjadwalan selanjutnya. Kemudian dengan menambahkan time window pada penjadwalan non delay tentunya akan berpengaruh dengan makespan yang dihasilkan. Hasil yang diperoleh dapat lebih besar atau lebih kecil, namun lebih realistik. Langkah penelitian secara lenkap dapat dilihat pada Gambar 1. 


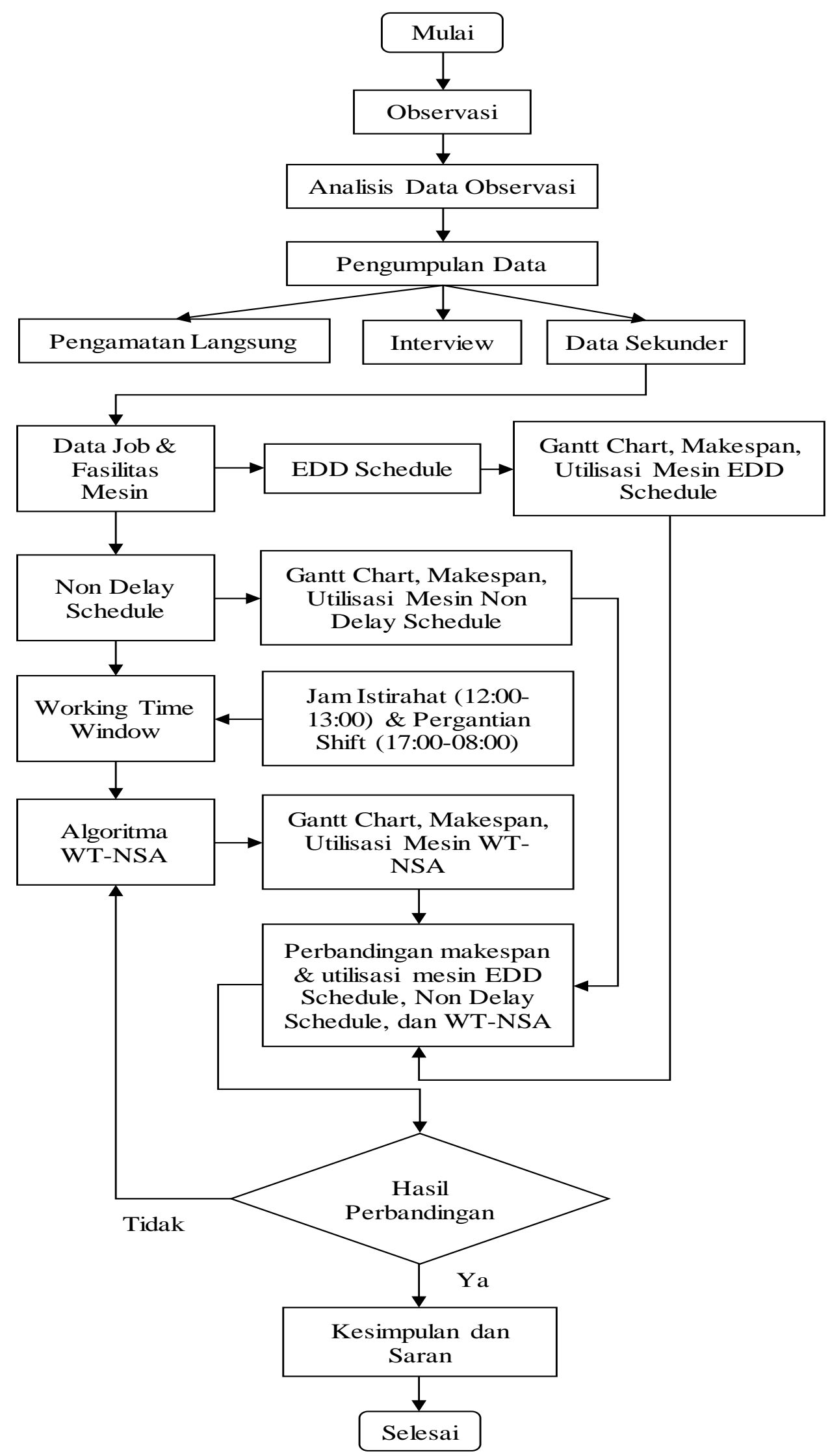

Gambar 1. Diagram Alir Langkah Penelitian 


\section{Hasil dan Perbandingan}

Data job yang masuk pada minggu pertama Mei 2016 adalah 11 job (A-K) dengan jumlah komponen secara keseluruhan sebanyak 53 komponen (lihat Tabel 1). Kemudian, fasilitas mesin yang dimiliki adalah sebanyak 13 mesin dengan tipe dan fungsi yang berbeda-beda (lihat Tabel 2).

Tabel 1. Daftar Job PT Autotech Perkasa Mandiri

\begin{tabular}{|c|l|c|c|}
\hline JOB & \multicolumn{1}{|c|}{ JOB NAME } & Jumlah Part & $\begin{array}{c}\text { Delivery } \\
\text { Date }\end{array}$ \\
\hline A & JIG STRENGHT FOOTREST 54P L/P, 14D L/R DAN 2PH R/L & 9 & $17-$ May-16 \\
\hline B & INSPECTION JIG P/N BG7-F1288-30 & 5 & $24-$ May-16 \\
\hline C & INSPECTION JIG P/N BG7-F1288-40 & 4 & $24-$ May-16 \\
\hline D & INSPECTION JIG P/N BG7-F1288-50 & 5 & $24-$ May-16 \\
\hline E & INSPECTION JIG P/N BG7-F1288-60 & 2 & $24-$ May-16 \\
\hline F & JIG Y0818-E3-K03-3 & 10 & $25-$ May-16 \\
\hline G & JIG SPOT WELDING GA240-18380 OP 1 & 7 & $25-$ May-16 \\
\hline H & INSPECTION JIG P/N 50179-K56A-N001 & 2 & $9-$ May-16 \\
\hline I & INSPECTION JIG P/N 50176-K56A-N001 & 2 & $10-$ May-16 \\
\hline J & INSPECTION JIG P/N 50171-K56A-N002 & 2 & $16-$ May-16 \\
\hline K & INSPECTION JIG P/N 50174-K56A-N002 & 5 & $18-$ May-16 \\
\hline
\end{tabular}

Tabel 2 Daftar Fasilitas Mesin PT Autotech Perkasa Mandiri

\begin{tabular}{|c|l|c|c|c|c|}
\hline No & \multicolumn{1}{|c|}{ Nama Mesin } & Spesifikasi & Brand & Jumlah & No. Mesin \\
\hline 1 & Milling Manual & $300 \times 1200$ & Hitachi & 4 & ML 01-ML 04 \\
\hline 2 & Lathe & $250 \times 1000$ & Kern & 1 & LT 01 \\
\hline 3 & Surface Grinding & $400 \times 800$ & Okamoto & 1 & SG 01 \\
\hline 4 & Cylinder Grinding & $120 \times 400$ & Standart & 1 & CG 01 \\
\hline 5 & CNC Milling & $800 \times 400 \times 400$ & Fanuc & 2 & CM 01-CM 02 \\
\hline 6 & CNC Lathe & $350 \times 600$ & Mazak & 1 & CL01 \\
\hline 7 & Wire Cut & $320 \times 260 \times 180$ & Fanuc & 1 & WC 01 \\
\hline 8 & Tapping & & Krisbow & 1 & TP 01 \\
\hline 9 & Drilling & & Krisbow & 1 & DL 01 \\
\hline
\end{tabular}

\subsection{EDD Schedule}

EDD schedule merupakan metode penjadwalan yang saat ini diterapkan oleh PT Autotech Perkasa Mandiri, dimana job yang memiliki due date yang paling awal di antara job-job lainnya dipilih sebagai job yang memiliki prioritas paling tinggi untuk diproses pada sebuah mesin. Berikut pada Tabel 3.3 dapat kita lihat bahwa Job H merupakan job dengan due date paling awal di antara job lainnya yaitu 9 Mei 2016, maka Job H diprioritaskan untuk diproses pada mesin. Selanjutnya, Job I dengan due date paling awal setelah Job H yaitu 10 Mei 2016 diprioritaskan untuk diproses pada mesin. Tabel 3 menampilkan perhitungan completion time seluruh job, yang disusun berdasarkan aturan earliest due date (EDD), dimana completion time terbesar merupakan makespan dari penjadwalan seluruh job tersebut. Kemudian dari Tabel 3 diperoleh part 42 pada Job G memiliki completion time paling besar, yaitu 38 jam 54 menit atau 38,9 jam. Dengan demikian dapat disimpulkan bahwa PT Autotech Perkasa Mandiri memerlukan 38 jam 54 menit untuk menyelesaikan 11 job dengan 53 part (lihat Tabel 1) dengan menggunakan 13 mesin (lihat Tabel 2). Maka makespan dari penjadwalan seluruh job tersebut adalah 38 jam 54 menit. Selain itu, completion date dan due date untuk tiap-tiap part/job tidak ada yang mengalami keterlambatan, karena seluruh part selesai sebelum due date yang diberikan.

\subsection{Algoritma Non-Delay Schedule}

Non delay schedule merupakan jadwal aktif pada sistem produksi job shop dengan aturan shortest processing time (SPT), yaitu memprioritaskan job dengan waktu proses paling singkat dengan ketetuan tidak ada mesin yang menganggur jika dapat memulai operasi tertentu. Tujuan dari metode ini adalah meminimasi makespan dan meningkatkan utilisasi mesin. Pada bab sebelumnya telah diperoleh makespan dari EDD schedule yaitu 38 jam 54 menit, maka pada bab ini akan dilakukan analisis dengan algoritma Non Delay Schedule dengan tujuan untuk meminimasi makespan 
dan meningkatkan utilisasi mesin. Selanjutnya, untuk mendapatkan operasi mana yang akan dijadwalkan terlebih dahulu, maka dengan menggunakan aturan shortest processing time (SPT), yaitu operasi dengan waktu proses paling kecil disusunlah iterasi seperti pada Tabel 4.

Tabel 3. Completion Time dan Makespan EDD Schedule

\begin{tabular}{|c|c|c|c|c|}
\hline \multicolumn{5}{|c|}{ EDD SCHEDULE } \\
\hline Job & Part & $\begin{array}{l}\text { Completion } \\
\text { Time (jam) }\end{array}$ & $\begin{array}{c}\text { Completion } \\
\text { Date }\end{array}$ & Due Date \\
\hline \multirow{2}{*}{$\mathrm{H}$} & Part 43 & 2,7 & 02-Mei-16 & \multirow{2}{*}{ 09-Mei-16 } \\
\hline & Part 44 & 2,9 & 02-Mei-16 & \\
\hline \multirow{2}{*}{ I } & Part 45 & 4,2 & 02-Mei-16 & \multirow{2}{*}{ 10-Mei-16 } \\
\hline & Part 46 & 11,7 & 03-Mei-16 & \\
\hline \multirow{9}{*}{ A } & Part 1 & 11,9 & 03-Mei-16 & \multirow{9}{*}{ 13-Mei-16 } \\
\hline & Part 2 & 12,1 & 03-Mei-16 & \\
\hline & Part 3 & 12,3 & 03-Mei-16 & \\
\hline & Part 4 & 15,2 & 03-Mei-16 & \\
\hline & Part 5 & 15,7 & 03-Mei-16 & \\
\hline & Part 6 & 16,2 & 04-Mei-16 & \\
\hline & Part 7 & 16,4 & 04-Mei-16 & \\
\hline & Part 8 & 8,50 & 03-Mei-16 & \\
\hline & Part 9 & 7,4 & 02-Mei-16 & \\
\hline \multirow{2}{*}{$\mathrm{J}$} & Part 47 & 8,4 & 03-Mei-16 & \multirow{2}{*}{ 16-Mei-16 } \\
\hline & Part 48 & 8,6 & 03-Mei-16 & \\
\hline \multirow{5}{*}{$\mathrm{K}$} & Part 49 & 16,6 & 04-Mei-16 & \multirow{5}{*}{ 18-Mei-16 } \\
\hline & Part 50 & 16,8 & 04-Mei-16 & \\
\hline & Part 51 & 13,7 & 03-Mei-16 & \\
\hline & Part 52 & 14,7 & 03-Mei-16 & \\
\hline & Part 53 & 15,7 & 03-Mei-16 & \\
\hline \multirow{5}{*}{ B } & Part 10 & 17 & 04-Mei-16 & \multirow{5}{*}{ 20-Mei-16 } \\
\hline & Part 11 & 17,2 & 04-Mei-16 & \\
\hline & Part 12 & 17,4 & 04-Mei-16 & \\
\hline & Part 13 & 17,6 & 04-Mei-16 & \\
\hline & Part 14 & 17,2 & 04-Mei-16 & \\
\hline \multirow{2}{*}{$\mathrm{C}$} & Part 15 & 18,4 & 04-Mei-16 & \multirow{2}{*}{ 20-Mei-16 } \\
\hline & Part 16 & 18,6 & 04-Mei-16 & \\
\hline
\end{tabular}

EDD SCHEDULE

\begin{tabular}{|c|c|c|c|c|}
\hline Job & Part & \begin{tabular}{|l} 
Completion \\
Time (jam) \\
\end{tabular} & $\begin{array}{c}\text { Completion } \\
\text { Date }\end{array}$ & Due Date \\
\hline \multirow{2}{*}{$\mathrm{C}$} & Part 17 & 18,9 & 04-Mei-16 & \multirow{2}{*}{ 20-Mei-16 } \\
\hline & Part 18 & 18,2 & 04-Mei-16 & \\
\hline \multirow{5}{*}{ D } & Part 19 & 19,9 & 04-Mei-16 & \multirow{5}{*}{ 20-Mei-16 } \\
\hline & Part 20 & 20,4 & 04-Mei-16 & \\
\hline & Part 21 & 20,6 & 04-Mei-16 & \\
\hline & Part 22 & 20,9 & 04-Mei-16 & \\
\hline & Part 23 & 21,2 & 04-Mei-16 & \\
\hline \multirow{2}{*}{$\mathrm{E}$} & Part 24 & 22,9 & 04-Mei-16 & \multirow{2}{*}{ 20-Mei-16 } \\
\hline & Part 25 & 22,7 & 04-Mei-16 & \\
\hline \multirow{10}{*}{$F$} & Part 26 & 26,2 & 05-Mei-16 & \multirow{10}{*}{ 23-Mei-16 } \\
\hline & Part 27 & 27,2 & 05-Mei-16 & \\
\hline & Part 28 & 28,7 & 05-Mei-16 & \\
\hline & Part 29 & 28,9 & 05-Mei-16 & \\
\hline & Part 30 & 30,2 & 05-Mei-16 & \\
\hline & Part 31 & 31,9 & 05-Mei-16 & \\
\hline & Part 32 & 31,2 & 05-Mei-16 & \\
\hline & Part 33 & 32,9 & 06-Mei-16 & \\
\hline & Part 34 & 33,4 & 06-Mei-16 & \\
\hline & Part 35 & 33,9 & 06-Mei-16 & \\
\hline \multirow{7}{*}{ G } & Part 36 & 35,4 & 06-Mei-16 & \multirow{7}{*}{ 23-Mei-16 } \\
\hline & Part 37 & 36,9 & 06-Mei-16 & \\
\hline & Part 38 & 36,7 & 06-Mei-16 & \\
\hline & Part 39 & 37,2 & 06-Mei-16 & \\
\hline & Part 40 & 37,6 & 06-Mei-16 & \\
\hline & Part 41 & 37,7 & 06-Mei-16 & \\
\hline & Part 42 & 38,9 & 06-Mei-16 & \\
\hline
\end{tabular}

Tabel 4 merupakan iterasi 1 dari non delay schedule, pada iterasi 1 routing operasi $j 1$ tiap-tiap part dimasukkan pada tabel, kemudian waktu proses tiap part dijumlahkan dengan waktu awal dimulainya operasi pada mesin tersebut $(r j=C j+t j)$, selanjutnya dipilihlah $r j$ yang terkecil. Pada Tabel 3.4 yang ditandai dengan warna merah adalah operasi yang terpilih. Part yang dapat memulai proses pada iterasi 1 yaitu part $9,16,17,20,21$, dan 32 . Kemudian pada iterasi berikutnya, operasi yang terpilih di iterasi 1 digantikan oleh operasi selanjutnya pada part tersebut. Selanjutnya proses yang sama pada iterasi 1 dilakukan, yaitu dengan memilih rj terkecil. Kemudian proses diulang hingga operasi seluruh part terpilih. 
Tabel 4. Iterasi 1 Non Delay Schedule

\begin{tabular}{|c|c|c|c|c|c|c|c|}
\hline Stage & St & Cj & tj & rj & $\mathrm{c}^{*}$ & $\mathrm{~m}^{*}$ & PSt \\
\hline & $(1,1,1)$ & 0 & 1 & 1 & 0,2 & 2 & $(9,1,2)$ \\
\hline$(2,1,1)$ & 0 & 1 & 1 & 0,5 & ML01 & $(16,1,1)$ \\
\hline$(3,1,1)$ & 0 & 1 & 1 & 0,5 & ML02 & $(17,1,1)$ \\
\hline$(4,1,1)$ & 0 & 1,5 & 1,5 & 0,5 & ML03 & $(20,1,1)$ \\
\hline$(5,1,1)$ & 0 & 1,5 & 1,5 & 0,5 & ML04 & $(21,1,1)$ \\
\hline$(6,1,1)$ & 0 & 1 & 1 & 1 & 6 & $(32,1,6)$ \\
\hline$(7,1,2)$ & 0 & 1 & 1 & & & \\
\hline$(8,1,2)$ & 0 & 2 & 2 & & & \\
\hline$(9,1,2)$ & 0 & 0,2 & 0,2 & & & \\
\hline$(10,1,1)$ & 0 & 1 & 1 & & & \\
\hline$(11,1,1)$ & 0 & 1 & 1 & & & \\
\hline$(12,1,1)$ & 0 & 1 & 1 & & & \\
\hline $1(13,1,1)$ & 0 & 1 & 1 & & & \\
\hline$(14,1,2)$ & 0 & 1 & 1 & & & \\
\hline$(15,1,1)$ & 0 & 1 & 1 & & & \\
\hline$(16,1,1)$ & 0 & 0,5 & 0,5 & & & \\
\hline$(17,1,1)$ & 0 & 0,5 & 0,5 & & & \\
\hline$(18,1,2)$ & 0 & 1 & 1 & & & \\
\hline$(19,1,1)$ & 0 & 1 & 1 & & & \\
\hline$(20,1,1)$ & 0 & 0,5 & 0,5 & & & \\
\hline$(21,1,1)$ & 0 & 0,5 & 0,5 & & & \\
\hline$(22,1,1)$ & 0 & 0,5 & 0,5 & & & \\
\hline$(23,1,2)$ & 0 & 1 & 1 & & & \\
\hline$(24,1,1)$ & 0 & 1 & 1 & & & \\
\hline$(25,1,1)$ & 0 & 0,5 & 0,5 & & & \\
\hline$(26,1,1)$ & 0 & 1 & 1 & & & \\
\hline$(27,1,2)$ & 0 & 1 & 1 & & & \\
\hline
\end{tabular}

\begin{tabular}{|c|c|c|c|c|c|c|c|}
\hline Stage & St & Cj & tj & rj & $\mathrm{c}^{*}$ & $\mathrm{~m}^{*}$ & PSt \\
\hline & & & & & & \\
\hline$(28,1,1)$ & 0 & 1 & 1 & & & \\
\hline$(29,1,1)$ & 0 & 1 & 1 & & & \\
\hline$(30,1,2)$ & 0 & 1 & 1 & & & \\
\hline$(31,1,2)$ & 0 & 1 & 1 & & & \\
\hline$(32,1,6)$ & 0 & 1 & 1 & & & \\
\hline$(33,1,2)$ & 0 & 1 & 1 & & & \\
\hline$(34,1,6)$ & 0 & 1 & 1 & & & \\
\hline$(35,1,6)$ & 0 & 1 & 1 & & & \\
\hline$(36,1,1)$ & 0 & 1 & 1 & & & \\
\hline$(37,1,1)$ & 0 & 2 & 2 & & & \\
\hline$(38,1,1)$ & 0 & 1 & 1 & & & \\
\hline$(39,1,1)$ & 0 & 1 & 1 & & & \\
\hline $140,1,2)$ & 0 & 1 & 1 & & & \\
\hline$(41,1,1)$ & 0 & 1 & 1 & & & \\
\hline$(42,1,2)$ & 0 & 1 & 1 & & & \\
\hline$(43,1,1)$ & 0 & 1 & 1 & & & \\
\hline$(44,1,1)$ & 0 & 1 & 1 & & & \\
\hline$(45,1,1)$ & 0 & 1 & 1 & & & \\
\hline$(46,1,1)$ & 0 & 0,5 & 0,5 & & \\
\hline$(47,1,1)$ & 0 & 0,5 & 0,5 & & \\
\hline$(48,1,1)$ & 0 & 0,5 & 0,5 & & \\
\hline$(49,1,6)$ & 0 & 1 & 1 & & & \\
\hline$(50,1,6)$ & 0 & 1 & 1 & & & \\
\hline$(51,1,2)$ & 0 & 1 & 1 & & & \\
\hline$(52,1,2)$ & 0 & 1 & 1 & & & \\
\hline$(53,1,2)$ & 0 & 1 & 1 & & & \\
\hline
\end{tabular}

Selanjutnya, pada Tabel 5 menunjukan completion time dan makespan untuk Non Delay Schedule. Berdasarkan Tabel 5, completion time paling besar adalah pada part 49 dengan waktu 23 jam 6 menit atau 23,1 jam, dengan demikian dapat disimpulkan bahwa makespan dari Non Delay Schedule untuk seluruh job adalah 23 jam 6 menit.

\subsection{Algoritma with Working Time Window}

Working time window adalah algoritma untuk menghitung finish time dengan memperhitungkan kendala ketersediaan mesin (machine avilability constraint). Pada bab sebelumnya telah diperoleh makespan dari Non Delay Schedule, yaitu sebesar 23 jam 6 menit namun tanpa memperhitungkan kendala ketersediaan mesin (machine availability constraint). Maka, agar lebih realistik untuk diterapkan kendala ketersediaan mesin perlu diperhitungkan. Selanjutnya, diasumsikan bahwa PT Autotech Perkasa Mandiri memiliki jam kerja dari jam 08:00-12:00 dan 13:00-17:00 (8 jam kerja) dengan jam istirahat (breaking period 1) dari jam 12:00-13:00 (1 jam) juga jam pergantian shift (breaking period 2) dari jam 17:00-08:00. Jam istirahat (breaking period 1) dan jam pergantian shift (breaking period 2) ini merupakan working time window yang akan diperhitungkan. 
Tabel 3.5 Completion Time dan Makespan Non Delay Schedule

\begin{tabular}{|c|c|c|c|c|}
\hline \multicolumn{5}{|c|}{ NON DELAY SCHEDULE } \\
\hline Job & Part & $\begin{array}{l}\text { Completion } \\
\text { Time (jam) }\end{array}$ & $\begin{array}{c}\text { Completion } \\
\text { Date }\end{array}$ & Due Date \\
\hline \multirow{9}{*}{$A$} & Part 1 & 5,4 & 02-Mei-16 & \multirow{9}{*}{ 13-Mei-16 } \\
\hline & Part 2 & 8,9 & 03-Mei-16 & \\
\hline & Part 3 & 2,7 & 02-Mei-16 & \\
\hline & Part 4 & 21,1 & 04-Mei-16 & \\
\hline & Part 5 & 22,3 & 04-Mei-16 & \\
\hline & Part 6 & 6,7 & 02-Mei-16 & \\
\hline & Part 7 & 2,4 & 02-Mei-16 & \\
\hline & Part 8 & 16,7 & 04-Mei-16 & \\
\hline & Part 9 & 0,4 & 02-Mei-16 & \\
\hline \multirow{5}{*}{ B } & Part 10 & 9,9 & 03-Mei-16 & \multirow{5}{*}{ 20-Mei-16 } \\
\hline & Part 11 & 4,2 & 02-Mei-16 & \\
\hline & Part 12 & 4,6 & 02-Mei-16 & \\
\hline & Part 13 & 5,2 & 02-Mei-16 & \\
\hline & Part 14 & 3,20 & 02-Mei-16 & \\
\hline \multirow{4}{*}{ C } & Part 15 & 11,6 & 03-Mei-16 & \multirow{4}{*}{ 20-Mei-16 } \\
\hline & Part 16 & 1,2 & 02-Mei-16 & \\
\hline & Part 17 & 1,4 & 02-Mei-16 & \\
\hline & Part 18 & 4,7 & 02-Mei-16 & \\
\hline \multirow{5}{*}{ D } & Part 19 & 12,6 & 03-Mei-16 & \multirow{5}{*}{ 20-Mei-16 } \\
\hline & Part 20 & 1,7 & 02-Mei-16 & \\
\hline & Part 21 & 1,9 & 02-Mei-16 & \\
\hline & Part 22 & 2,2 & 02-Mei-16 & \\
\hline & Part 23 & 5,70 & 02-Mei-16 & \\
\hline \multirow{2}{*}{$E$} & Part 24 & 13,6 & 03-Mei-16 & \multirow{2}{*}{$20-M e i-16$} \\
\hline & Part 25 & 3 & 02-Mei-16 & \\
\hline \multirow{2}{*}{$F$} & Part 26 & 18,8 & 04-Mei-16 & \multirow{2}{*}{ 23-Mei-16 } \\
\hline & Part 27 & 15,4 & 03-Mei-16 & \\
\hline
\end{tabular}

NON DELAY SCHEDULE

\begin{tabular}{|c|c|c|c|c|}
\hline Job & Part & $\begin{array}{l}\text { Completion } \\
\text { Time (jam) }\end{array}$ & $\begin{array}{c}\text { Completion } \\
\text { Date }\end{array}$ & Due Date \\
\hline \multirow{8}{*}{$F$} & Part 28 & 17,2 & 04-Mei-16 & \multirow{8}{*}{ 23-Mei-16 } \\
\hline & Part 29 & 16,4 & 04-Mei-16 & \\
\hline & Part 30 & 21,9 & 04-Mei-16 & \\
\hline & Part 31 & 11,1 & 02-Mei-16 & \\
\hline & Part 32 & 7,5 & 02-Mei-16 & \\
\hline & \begin{tabular}{|l|} 
Part 33 \\
\end{tabular} & 9,4 & 03-Mei-16 & \\
\hline & Part 34 & 3,4 & 02-Mei-16 & \\
\hline & Part 35 & 4,4 & 02-Mei-16 & \\
\hline \multirow{7}{*}{ G } & Part 36 & 6,2 & 02-Mei-16 & \multirow{7}{*}{ 23-Mei-16 } \\
\hline & Part 37 & 22,1 & 04-Mei-16 & \\
\hline & Part 38 & 7,7 & 02-Mei-16 & \\
\hline & Part 39 & 8,20 & 03-Mei-16 & \\
\hline & Part 40 & 10,1 & 03-Mei-16 & \\
\hline & Part 41 & 6,5 & 02-Mei-16 & \\
\hline & Part 42 & 10,9 & 03-Mei-16 & \\
\hline \multirow{2}{*}{$\mathrm{H}$} & \begin{tabular}{|l|} 
Part 43 \\
\end{tabular} & 6,7 & 02-Mei-16 & \multirow{2}{*}{ 09-Mei-16 } \\
\hline & Part 44 & 7,20 & 02-Mei-16 & \\
\hline \multirow{2}{*}{ I } & Part 45 & 8,70 & 03-Mei-16 & \multirow{2}{*}{ 10-Mei-16 } \\
\hline & Part 46 & 3,2 & 02-Mei-16 & \\
\hline \multirow{2}{*}{$\mathrm{J}$} & Part 47 & 2 & 02-Mei-16 & \multirow{2}{*}{ 16-Mei-16 } \\
\hline & Part 48 & 2,5 & 02-Mei-16 & \\
\hline \multirow{5}{*}{ K } & Part 49 & 23,1 & 04-Mei-16 & \multirow{5}{*}{ 18-Mei-16 } \\
\hline & Part 50 & 9,6 & 03-Mei-16 & \\
\hline & Part 51 & 19,7 & 04-Mei-16 & \\
\hline & Part 52 & 20,7 & 04-Mei-16 & \\
\hline & Part 53 & 21,7 & 04-Mei-16 & \\
\hline
\end{tabular}

\subsection{Algoritma Non-Delay Schedule dengan Working Time Window}

Pada bab sebelumnya telah diasumsikan bahwa PT Autotech Perkasa Mandiri memiliki jam kerja dari jam 08:00-12:00 dan 13:00-17:00 (8 jam kerja) dengan jam istirahat (breaking period 1) dari jam 12:00-13:00 (1 jam) juga jam pergantian shift (breaking period 2) dari jam 17:00-08:00, maka pada bab ini akan dilakukan analisis Non Delay Schedule dengan Working Time Window. Tujuan dari metode ini adalah meminimasi makespan dengan tetap memperhitungkan kendala ketersediaan mesin, sehingga dapat diaplikasikan ke dalam permasalahan yang sebenarnya. Tabel 6 merupakan tabel iterasi 5 Non-Delay Schedule yang terjadi breaking period dari operasi yang terpilih. 
Tabel 6. Iterasi 5 Non Delay Schedule

\begin{tabular}{|c|c|c|c|c|c|c|c|}
\hline Stage & St & $\mathrm{Cj}$ & $\mathrm{tj}$ & rj & $C^{*}$ & $\mathrm{~m}^{*}$ & PSt \\
\hline \multirow{25}{*}{5} & $(1,2,3)$ & 1 & 1 & 2 & 1 & ML01 & $(13,1,1)$ \\
\hline & $(2,2,3)$ & 1 & 1 & 2 & 1 & ML02 & $(15,1,1)$ \\
\hline & $(3,3,8)$ & 1,5 & 0,2 & 1,7 & 1 & ML03 & $(19,1,1)$ \\
\hline & $(4,1,1)$ & 0 & 1,5 & 1,5 & 1 & 2 & $(23,1,2)$ \\
\hline & $(5,1,1)$ & 0 & 1,5 & 1,5 & 1 & ML04 & $(24,1,1)$ \\
\hline & $(6,2,3)$ & 1 & 0,5 & 1,5 & 1 & 3 & $(25,2,3)$ \\
\hline & $(7,3,8)$ & 1,5 & 0,2 & 1,7 & 1 & 6 & $(50,1,6)$ \\
\hline & $(8,1,2)$ & 0 & 2 & 2 & 1,2 & 8 & $(20,3,8)$ \\
\hline & $(10,2,3)$ & 1 & 1 & 2 & 1,2 & CMO2 & $(48,3,5)$ \\
\hline & $(11,2,5)$ & 1 & 1 & 2 & 1,5 & CM01 & $(46,2,5)$ \\
\hline & $(12,2,5)$ & 1 & 1 & 2 & 1,5 & 4 & $(18,2,4)$ \\
\hline & $(13,1,1)$ & 0 & 1 & 1 & 2 & 7 & $(14,3,7)$ \\
\hline & $(14,3,7)$ & 1,5 & 0,5 & 2 & & & \\
\hline & $(15,1,1)$ & 0 & 1 & 1 & & & \\
\hline & $(18,2,4)$ & 1 & 0,5 & 1,5 & & & \\
\hline & $(19,1,1)$ & 0 & 1 & 1 & & & \\
\hline & $(20,3,8)$ & 1 & 0,2 & 1,2 & & & \\
\hline & $(21,3,8)$ & 1 & 0,2 & 1,2 & & & \\
\hline & $(22,3,8)$ & 1 & 0,2 & 1,2 & & & \\
\hline & $(23,1,2)$ & 0 & 1 & 1 & & & \\
\hline & $(24,1,1)$ & 0 & 1 & 1 & & & \\
\hline & $(25,2,3)$ & 0,5 & 0,5 & 1 & & & \\
\hline & $(26,1,1)$ & 0 & 1 & 1 & & & \\
\hline & $(27,1,2)$ & 0 & 1 & 1 & & & \\
\hline & $(28,1,1)$ & 0 & 1 & 1 & & & \\
\hline
\end{tabular}

\begin{tabular}{|c|c|c|c|c|c|c|c|}
\hline Stage & St & $C_{j}$ & $\mathrm{tj}$ & $r j$ & $c^{*}$ & $\mathrm{~m}^{*}$ & PSt \\
\hline \multirow{24}{*}{5} & $(29,1,1)$ & 0 & 1 & 1 & & & \\
\hline & $(30,1,2)$ & 0 & 1 & 1 & & & \\
\hline & $(31,1,2)$ & 0 & 1 & 1 & & & \\
\hline & $(32,2,1)$ & 1 & 0,5 & 1,5 & & & \\
\hline & $(33,1,2)$ & 0 & 1 & 1 & & & \\
\hline & $(34,2,4)$ & 1 & 0,5 & 1,5 & & & \\
\hline & $(35,2,4)$ & 1 & 0,5 & 1,5 & & & \\
\hline & $(36,1,1)$ & 0 & 1 & 1 & & & \\
\hline & $(37,1,1)$ & 0 & 2 & 2 & & & \\
\hline & $(38,1,1)$ & 0 & 1 & 1 & & & \\
\hline & $(39,1,1)$ & 0 & 1 & 1 & & & \\
\hline & $(40,1,2)$ & 0 & 1 & 1 & & & \\
\hline & $(41,1,1)$ & 0 & 1 & 1 & & & \\
\hline & $(42,1,2)$ & 0 & 1 & 1 & & & \\
\hline & $(43,1,1)$ & 0 & 1 & 1 & & & \\
\hline & $(44,1,1)$ & 0 & 1 & 1 & & & \\
\hline & $(45,1,1)$ & 0 & 1 & 1 & & & \\
\hline & $(46,2,5)$ & 0,5 & 1 & 1,5 & & & \\
\hline & $(48,3,5)$ & 0,7 & 0,5 & 1,2 & & & \\
\hline & $(49,2,1)$ & 1 & 1 & 2 & & & \\
\hline & $(50,1,6)$ & 0 & 1 & 1 & & & \\
\hline & $(51,1,2)$ & 0 & 1 & 1 & & & \\
\hline & $(52,1,2)$ & 0 & 1 & 1 & & & \\
\hline & $(53,1,2)$ & 0 & 1 & 1 & & & \\
\hline
\end{tabular}

Berikut merupakan perhitungan finish time untuk operasi yang terpilih dari iterasi 5 Non Delay Schedule pada Tabel 6 :

$f_{1,13}=10: 30+01: 00=11: 30$

$f_{1,15}=11: 00+01: 00=12: 00$

$f_{1,19}=11: 00+01: 00=12: 00$

$f_{2,23}=11: 12+01: 00=12: 12$

$$
\begin{aligned}
& f_{1,24}=11: 00+01: 00=12: 00 \\
& f_{3,25}=09: 42+00: 30=10: 12 \\
& f_{6,50}=13: 00+01: 00=14: 00 \\
& f_{8,20}=09: 30+00: 12=09: 42
\end{aligned}
$$

Dari hasil perhitungan di atas menunjukan bahwa operasi yang terpilih dari iterasi 5 pada tabel 3.6 ada terjadi breaking period, yaitu pada operasi $\mathrm{f}_{2,23}(23,1,2)$. Berikut adalah perhitungan finish time baru untuk operasi $f_{2,23}(23,1,2)$ :
$b_{1}=t_{2,23} \leq \mu_{1,1} \leq f_{2,23}$
$\mu_{\mathrm{a}, \mathrm{B}}$ )
$b_{1}=11: 12 \leq 12: 00 \leq 12: 12$ (true)
$b_{2}=t_{2,23} \leq \gamma_{1,1} \leq f_{2,23}$
$b_{2}=11: 12 \leq 13: 00 \leq 12: 12$ (false)
$b_{3}=\mu_{1,1} \leq t_{2,23} \leq \gamma_{1,1}$
$b_{3}=12: 00 \leq 11: 12 \leq 13: 00(0)$
$b_{4}=\mu_{1,1} \leq f_{2,23} \leq \gamma_{1,1}$
$b_{4}=12: 00 \leq 12: 12 \leq 13: 00$ (1)

$$
\begin{aligned}
& f_{5,48}=10: 00+00: 30=10: 30 \\
& f_{5,46}=10: 00+01: 00=11: 00 \\
& f_{4,18}=11: 12+00: 30=11: 42 \\
& f_{7,14}=10: 42+00: 30=11: 12
\end{aligned}
$$

$$
\begin{aligned}
& \mathrm{b}_{1} \wedge \sim \mathrm{b}_{2} \wedge \sim \mathrm{b}_{3} \wedge \mathrm{b}_{4}, \text { maka }: \mathrm{t}_{\mathrm{i}, \mathrm{j}}=\mu_{\mathrm{a}, \mathrm{B}} \text { dan } \mathrm{f}_{\mathrm{i}, \mathrm{j}}=\mathrm{f}_{\mathrm{i}, \mathrm{j}}+\left(\gamma_{\mathrm{a}, \mathrm{B}}-\right. \\
& \mathrm{t}_{2,23}=13: 00 \text { dan } \mathrm{f}_{2,23}=12: 12+(13: 00-12: 00) \\
& \mathrm{t}_{2,23}=12: 00 \text { dan } \mathrm{f}_{2,23}=13: 12
\end{aligned}
$$


Dari perhitungan di atas diperoleh finish time baru untuk operasi $(23,1,2)$ yaitu $13: 12$. Selanjutnya, perhitungan finish time dilakukan hingga seluruh operasi terjadwalkan, dengan pedoman, apabila tidak terjadi breaking period maka $\mathrm{f}_{\mathrm{i}, \mathrm{j}}=\mathrm{t}_{\mathrm{i}, \mathrm{j}}+\mathrm{p}_{\mathrm{i}, \mathrm{j}}$, lalu apabila terjadi breaking period maka perhitungan finish time sama seperti dengan operasi $(23,1,2)$ di atas. Berikut pada Tabel 7 menunjukkan completion time dan makespan untuk Non-Delay Schedule dengan Working Time Window.

Tabel 7. Completion Time dan Makespan Non-Delay Schedule dengan Working Time Window

\begin{tabular}{|c|c|c|c|c|}
\hline \multicolumn{5}{|c|}{ WT-NSA } \\
\hline Job & Part & $\begin{array}{l}\text { Completion } \\
\text { Time (jam) }\end{array}$ & $\begin{array}{c}\text { Completion } \\
\text { Date }\end{array}$ & Due Date \\
\hline \multirow{9}{*}{ A } & Part 1 & 6,4 & 02-Mei-16 & \multirow{9}{*}{$13-M e i-16$} \\
\hline & Part 2 & 9,9 & 03-Mei-16 & \\
\hline & Part 3 & 2,7 & 02-Mei-16 & \\
\hline & Part 4 & 24,1 & 04-Mei-16 & \\
\hline & Part 5 & 25,3 & 04-Mei-16 & \\
\hline & Part 6 & 7,7 & 02-Mei-16 & \\
\hline & Part 7 & 2,4 & 02-Mei-16 & \\
\hline & Part 8 & 18,7 & 04-Mei-16 & \\
\hline & Part 9 & 0,4 & 02-Mei-16 & \\
\hline \multirow{5}{*}{ B } & Part 10 & 10,9 & 03-Mei-16 & \multirow{5}{*}{ 20-Mei-16 } \\
\hline & Part 11 & 5,2 & 02-Mei-16 & \\
\hline & Part 12 & 5,6 & 02-Mei-16 & \\
\hline & Part 13 & 6,2 & 02-Mei-16 & \\
\hline & Part 14 & 3,20 & 02-Mei-16 & \\
\hline \multirow{4}{*}{ C } & Part 15 & 12,6 & 03-Mei-16 & \multirow{4}{*}{ 20-Mei-16 } \\
\hline & Part 16 & 1,2 & 02-Mei-16 & \\
\hline & Part 17 & 1,4 & 02-Mei-16 & \\
\hline & Part 18 & 5,7 & 02-Mei-16 & \\
\hline \multirow{5}{*}{ D } & Part 19 & 14,6 & 03-Mei-16 & \multirow{5}{*}{ 20-Mei-16 } \\
\hline & Part 20 & 1,7 & 02-Mei-16 & \\
\hline & Part 21 & 1,9 & 02-Mei-16 & \\
\hline & Part 22 & 2,2 & 02-Mei-16 & \\
\hline & Part 23 & 6,70 & 02-Mei-16 & \\
\hline \multirow{2}{*}{$E$} & Part 24 & 15,6 & 03-Mei-16 & \multirow{2}{*}{$20-M e i-16$} \\
\hline & Part 25 & 3 & 02-Mei-16 & \\
\hline \multirow{2}{*}{$F$} & Part 26 & 20,7 & 04-Mei-16 & \multirow{2}{*}{ 23-Mei-16 } \\
\hline & Part 27 & 17,4 & 04-Mei-16 & \\
\hline
\end{tabular}

\begin{tabular}{|c|c|c|c|c|}
\hline \multicolumn{5}{|c|}{ WT-NSA } \\
\hline Job & Part & $\begin{array}{l}\text { Completion } \\
\text { Time (jam) }\end{array}$ & $\begin{array}{c}\text { Completion } \\
\text { Date }\end{array}$ & Due Date \\
\hline \multirow{8}{*}{$\mathrm{F}$} & Part 28 & 19,2 & 04-Mei-16 & \multirow{8}{*}{ 23-Mei-16 } \\
\hline & Part 29 & 18,4 & 04-Mei-16 & \\
\hline & Part 30 & 24,9 & 04-Mei-16 & \\
\hline & Part 31 & 12,1 & 03-Mei-16 & \\
\hline & Part 32 & 8,5 & 02-Mei-16 & \\
\hline & Part 33 & 10,4 & 03-Mei-16 & \\
\hline & Part 34 & 3,4 & 02-Mei-16 & \\
\hline & Part 35 & 5,4 & 02-Mei-16 & \\
\hline \multirow{7}{*}{$\mathrm{G}$} & Part 36 & 7,2 & 02-Mei-16 & \multirow{7}{*}{ 23-Mei-16 } \\
\hline & Part 37 & 25,1 & 04-Mei-16 & \\
\hline & Part 38 & 8,7 & 02-Mei-16 & \\
\hline & Part 39 & 9,20 & 03-Mei-16 & \\
\hline & Part 40 & 11,1 & 03-Mei-16 & \\
\hline & \begin{tabular}{|l|} 
Part 41 \\
\end{tabular} & 7,5 & 02-Mei-16 & \\
\hline & Part 42 & 11,9 & 03-Mei-16 & \\
\hline \multirow{2}{*}{$\mathrm{H}$} & Part 43 & 7,7 & 02-Mei-16 & \multirow{2}{*}{ 09-Mei-16 } \\
\hline & Part 44 & 8,20 & 02-Mei-16 & \\
\hline \multirow{2}{*}{ I } & Part 45 & 9,70 & 03-Mei-16 & \multirow{2}{*}{ 10-Mei-16 } \\
\hline & Part 46 & 3,2 & 02-Mei-16 & \\
\hline \multirow{2}{*}{$\mathrm{J}$} & Part 47 & 2 & 02-Mei-16 & \multirow{2}{*}{$16-M e i-16$} \\
\hline & Part 48 & 2,5 & 02-Mei-16 & \\
\hline \multirow{5}{*}{ K } & Part 49 & 26,1 & 04-Mei-16 & \multirow{5}{*}{ 18-Mei-16 } \\
\hline & Part 50 & 10,6 & 03-Mei-16 & \\
\hline & Part 51 & 21,7 & 04-Mei-16 & \\
\hline & Part 52 & 23,7 & 04-Mei-16 & \\
\hline & Part 53 & 24,7 & 04-Mei-16 & \\
\hline
\end{tabular}

Dari Tabel 7 diperoleh bahwa completion time paling besar yaitu pada part 49 dengan waktu 26 jam 6 menit atau 26,1 jam, dengan demikian dapat disimpulkan bahwa makespan dari Non Delay Schedule dengan Working Time Window untuk seluruh job adalah 26 jam 6 menit. Gantt chart dari penjadwalan non-delay WT-NSA dapat dilihat pada lampiran.

\subsection{Perbandingan}

Tujuan dari penelitian ini adalah mendapatkan usulan penjadwalan job shop yang optimal yang dapat diaplikasikan ke dalam permasalahan yang sebenarnya. Hasil yang dapat diukur dari analisis penjadwalan yang dilakukan adalah makespan dan utilisasi mesin. Untuk itu dari hasil analisis yang dilakukan dengan algoritma Non-Delay Schedule dan hasil analisis dengan algoritma WT-NSA akan 
dibandingkan dengan kondisi aktual perusahaan. Selanjutnya, apabila hasil perbandingan dengan metode yang diusulkan lebih baik daripada kondisi aktual perusahaan, maka usulan dapat diterima untuk menjadi masukan pada penjadwalan selanjutnya. Algoritma WT-NSA merupakan algoritma yang dikembangkan dari Non Delay Schedule, yaitu dengan memperhitungkan machine availability constraint (kendala ketersediaan mesin) agar lebih realistik.

Pada sub bab 3.2 sebelumnya telah dilakukan analisis dengan metode penjadwalan non delay, yang kemudian diperoleh kesimpulan, bahwa untuk menyelesaikan 53 part dari 11 job memerlukan makespan 23 jam 6 menit atau 23,1 jam. Selanjutnya pada bab 3.4 juga telah dilakukan analisis dengan algoritma WT-NSA, yang juga diperoleh kesimpulan, bahwa untuk menyelesaikan job yang sama dengan memperhitungkan jam istirahat (12:00-13:00) dan pergantian shift (17:00-08:00) memerlukan makespan 26 jam 6 menit. Kemudian hasil dari analisis dengan penjadwalan non delay dan WT-NSA dibandingkan dengan kondisi aktual perusahaan, yaitu membandingkan makespan. Hal ini dilakukan untuk mengetahui apakah usulan dari penerapan metode penjadwalan non delay dengan working time window (WT-NSA) dapat diterima untuk penjadwalan selanjutnya.

Setelah dilakukan analisis dan perhitungan, ternyata makespan dari penjadwalan non delay dengan working time window (WT-NSA) lebih kecil dari makespan dari kondisi aktual perusahaan. Hal tersebut didukung dan dapat dilihat pada bab 3.2 dan 3.4 dimana makespan dari penjadwalan non delay adalah 23,1 jam, dan makespan dari algoritma WT-NSA adalah 26,1 jam, sedangkan pada bab 3.1 kita peroleh makespan dari kondisi aktual perusahaan adalah 38,9 jam. Maka, algoritma non delay schedule dengan working time window (WT-NSA) dapat diterima untuk penjadwalan berikutnya karena dapat meminimasi makespan dan lebih realistik apabila diaplikasikan dalam permasalahan yang sebenarnya, karena memperhitungkan machine availability constraint, yaitu jam istirahat (12:00-13:00) dan pergantian shift (17:00-08:00). Berikut pada Tabel 8 menyajikan perbandingan makespan dari analisis yang telah dilakukan.

Tabel 8. Perbandingan Makespan

\begin{tabular}{|c|l|c|}
\hline No. & Penjadwalan & Makespan \\
\hline 1 & EDD & 38 Jam 54 Menit \\
\hline 2 & NSA & 23 Jam 6 Menit \\
\hline 3 & WT-NSA & 26 Jam 6 Menit \\
\hline
\end{tabular}

Berdasarkan Tabel 8, makespan dari penjadwalan EDD adalah 38 jam 54 menit, sedangkan makespan dari penjadwalan non delay adalah 23 jam 6 menit, dan makespan dari penjadwalan non delay dengan working time window adalah 26 jam 6 menit. Makespan dari penjadwalan non delay merupakan hasil paling kecil, namun demikian tidak realistik karena tidak memperhitungkan kendala ketersediaan mesin. Sedangkan makespan dari penjadwalan non delay dengan working time window lebih kecil dari penjadwalan EDD dan realistik karena memperhitungkan kendala ketersediaan mesin. Selain itu, akan dilakukan perbandingan antara utilisasi mesin. Tabel 9 menyajika perbandingan utilisasi mesin dari ketiga metode.

Tabel 9. Perbandingan Utilisasi Mesin

\begin{tabular}{|c|c|c|c|c|c|c|c|}
\hline \multirow{2}{*}{ Machine } & \multicolumn{3}{|c|}{ Utilisasi } & \multirow{2}{*}{ Machine } & \multicolumn{3}{|c|}{ Utilisasi } \\
\cline { 2 - 3 } & EDD & NSA & WT-NSA & & EDD & NSA & WT-NSA \\
\hline ML01 & $20 \%$ & $37 \%$ & $33 \%$ & CM01 & $29 \%$ & $52 \%$ & $25 \%$ \\
\hline ML02 & $20 \%$ & $35 \%$ & $31 \%$ & CM02 & $29 \%$ & $28 \%$ & $29 \%$ \\
\hline ML03 & $23 \%$ & $33 \%$ & $29 \%$ & CL01 & $10 \%$ & $18 \%$ & $16 \%$ \\
\hline ML04 & $16 \%$ & $33 \%$ & $29 \%$ & WC01 & $7 \%$ & $13 \%$ & $12 \%$ \\
\hline LT01 & $40 \%$ & $68 \%$ & $61 \%$ & TP01 & $11 \%$ & $23 \%$ & $20 \%$ \\
\hline SG01 & $51 \%$ & $61 \%$ & $58 \%$ & DL01 & $10 \%$ & $18 \%$ & $16 \%$ \\
\hline CG01 & $25 \%$ & $44 \%$ & $39 \%$ & \multicolumn{3}{|c}{} \\
\hline
\end{tabular}

Dari Tabel 9 diperoleh bahwa utilisasi mesin dengan non delay schedule maupun non delay schedule dengan working time window lebih tinggi dibandingkan dengan EDD schedule.

\section{Kesimpulan}

Berdasarkan analisis dan pengolahan data yang telah dilakukan, maka diperoleh kesimpulan, yaitu algoritma non delay schedule dengan working time window dapat meminimasi makespan 15 jam 48 menit dan 
meningkatkan rata-rata utilisasi mesin sebesar $13 \%$. Selain itu, algoritma non delay schedule dengan working time window lebih realistik untuk diterapkan karena memperhitungkan kendala ketersediaan mesin, yaitu jam istirahat (12:00 - 13:00) dan pergantian shift (17:00 - 08:00).

\section{Daftar Pustaka}

1. Baker, K. R. (1974). Introduction to Sequencing and Scheduling, John Wiley, NY.

2. Baker, K. R. (1995). Element of Sequencing and Scheduling, Kenneth R. Baker, Tuck School of Bussiness Administration, Dartmouth College, Hanover, $\mathrm{NH}$.

3. Campbell, H. G., Dudek, R. A., and Smith, M. L. (1970). A Heuristic Algorithm for the $\mathrm{n}$ Job $\mathrm{m}$ Machine Sequencing Problem, Management Science, Vol.16, pp. B630-B637.

4. Giffler, B., and Thompson, G. L. (1960). Algorithms for Solving Production Scheduling Problems, Operation Research, Vol. 8, pp. 487-503.

5. Pinedo, M., dan Chao, X.,(1992). A Parametric Adjusment Method for Dispatching, Technical Report, Department of Industrial Engineering adn Operation Research, Columbia University, New York, NY.

6. Pinedo, M., and Chao, X. (1999). Operations Scheduling with Applications in Manufacturing and Services, Irwin / McGraw-Hill, Burr Ridge, Illinois.

7. Ploydanai, K., and Mungwattana, A. (2010). Algorithm for Solving Job Shop Scheduling Problem Based on Machine Availability Constraint, Department of Industrial Engineering, Faculty of Engineering, Kasetsart University, Bangkok, Thailand.

8. Setiady, S. (2016). Usulan Penerapan Non Delay Schedule untuk Meminimasi Makespan di PT Autotech Perkasa Mandiri, Program Studi Teknik Industri, Fakultas Teknik, President University, Cikarang, Indonesia. 
LAMPIRAN: GANTT CHART PENJADWALAN NON-DELAY WT-NSA

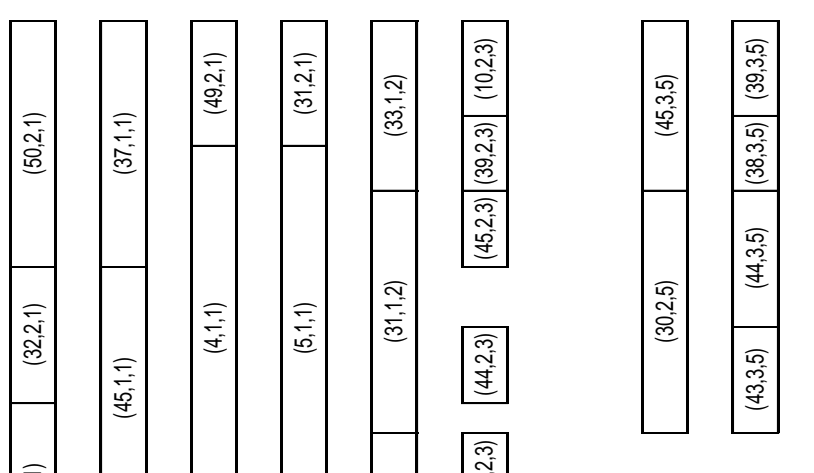

吝

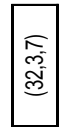

8
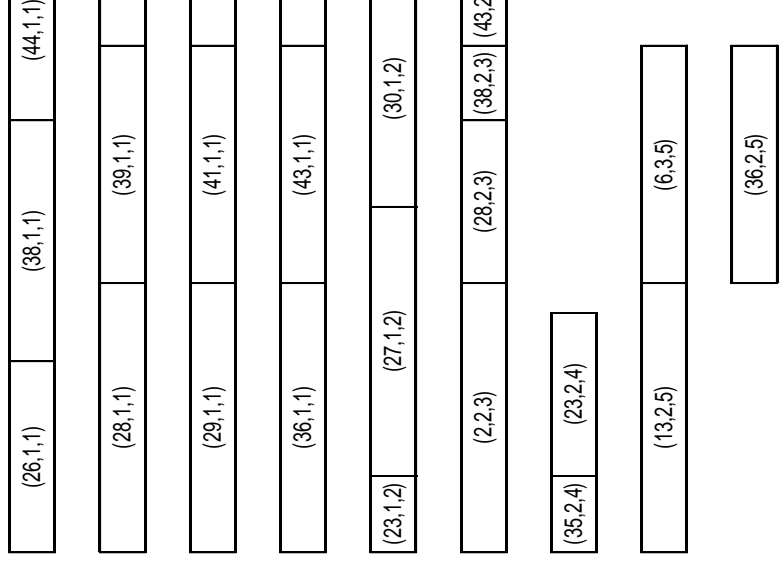

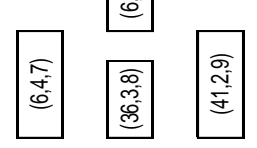

용

م.

高

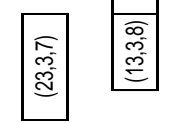

官

过

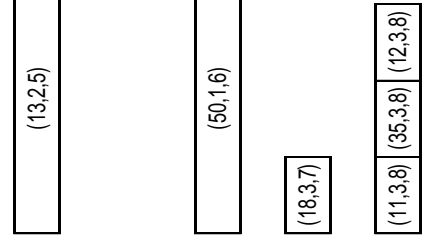

\begin{tabular}{c} 
a \\
\multirow{5}{*}{$=$} \\
$\stackrel{0}{=}$
\end{tabular}

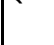

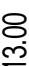

응

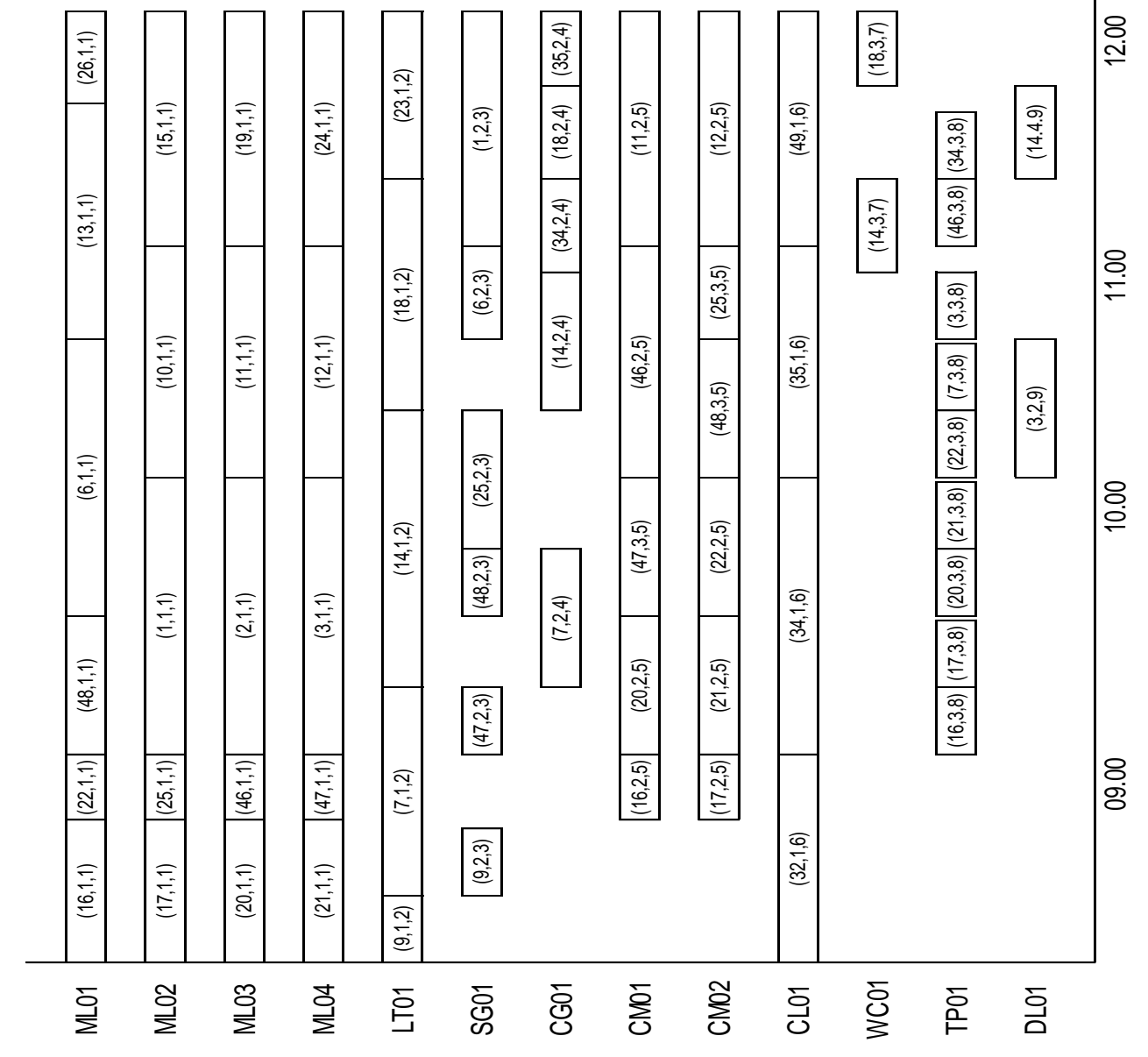

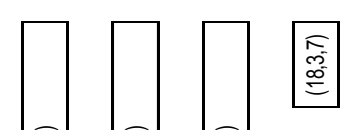

온 
JIE, Vol. 5, No.1, April 2020: 61-76

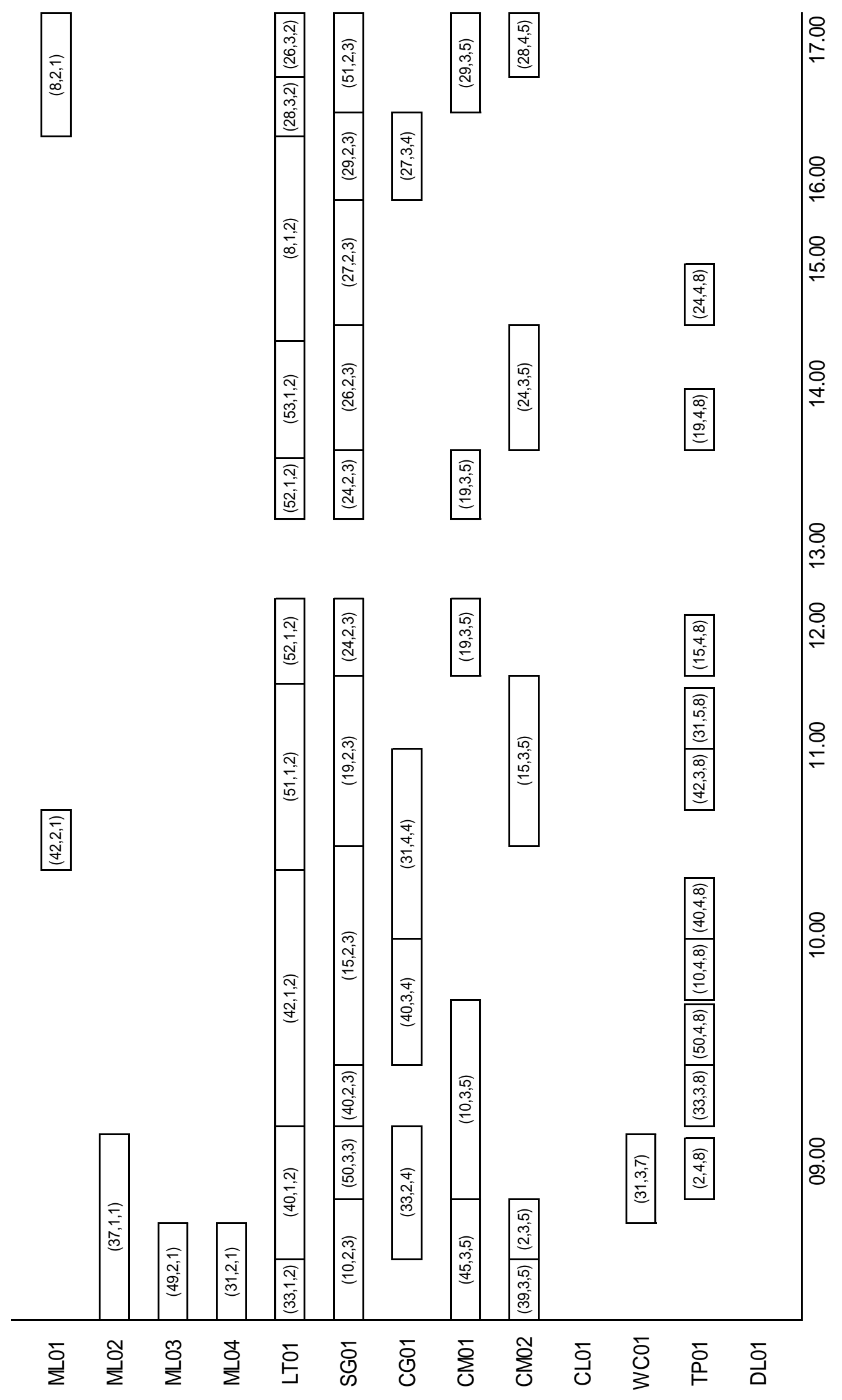


JIE, Vol. 5, No.1, April 2020: 61-76

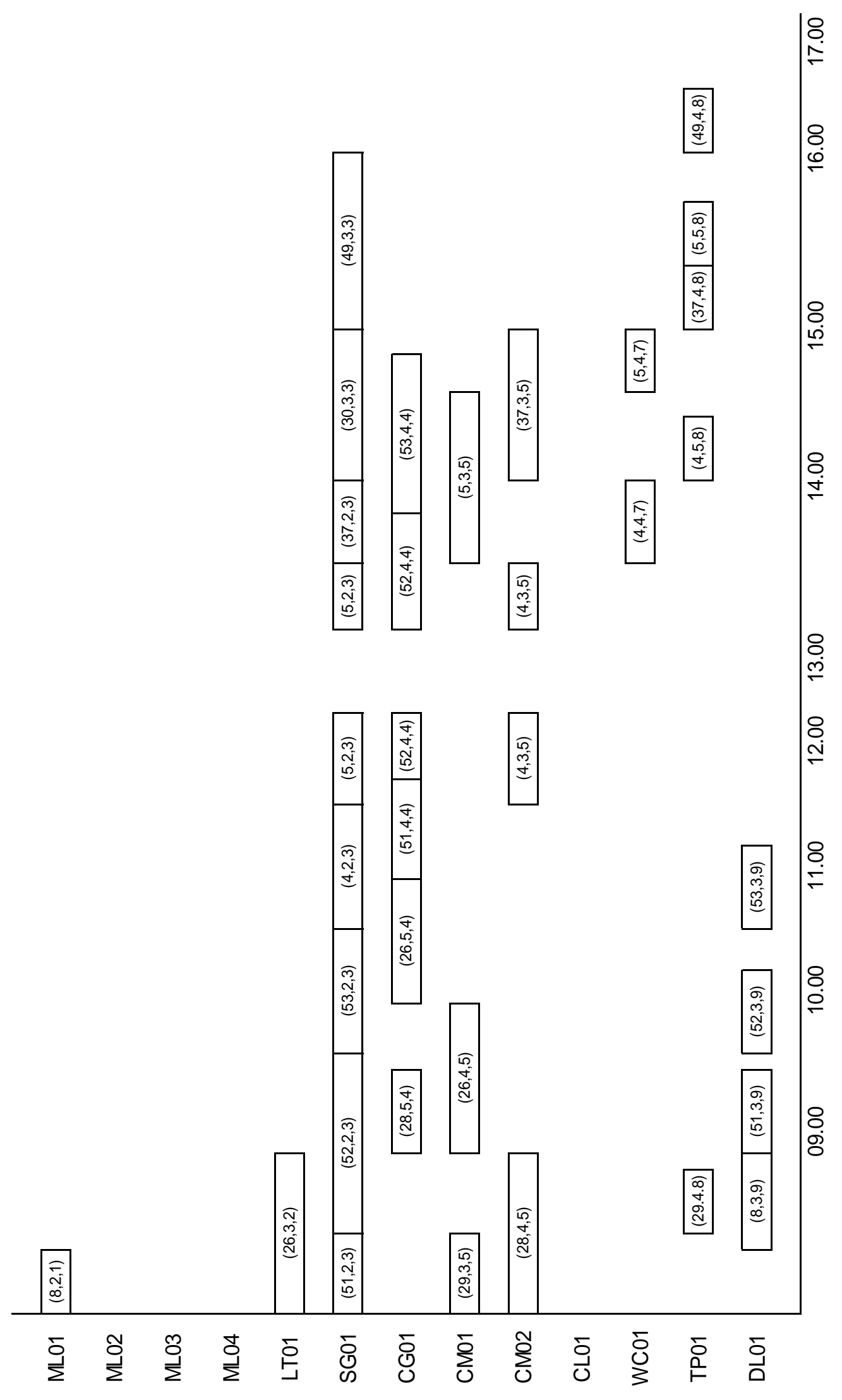

